\title{
ACTINIDES FILTERING OUT IN THE DEMO-IMITATION SEPARATOR WITH A MAGNETIC FIELD OF A GIVEN CONFIGURATION
}

\author{
V.B. Yuferov, V.V. Katrechko, V.O. Ilichova, S.N. Khizhnyak \\ National Science Center "Kharkov Institute of Physics and Technology”, Kharkiv, Ukraine \\ E-mail:v.yuferov@kipt.kharkov.ua
}

To simulate spent nuclear fuel (SNF) cleaning up from fission products, the concept of a demonstration-imitation separator (DIS) with a plasma rotating in crossed electric and magnetic fields is being clarified. The parameters of a magnetic system consisting of a combination of superconducting and water-cooled windings are presented. The features of plasma drift in a magnetic field of a given geometry are pointed. The estimation of energy consumption for the creation of a magnetic field of the separator, which is $\sim 250 \mathrm{~kW}$, has been carried out. A method for removing actinides from a plasma separator into an external container is proposed.

PACS: $28.41 \mathrm{Kw}$

\section{INTRODUCTION}

Earlier, in order to purify the plasma from impurities, the motion of plasma in magnetic fields of various configurations was investigated. In [1], a method is considered for the selection of heated ions in a curvilinear magnetic field for processing spent nuclear fuel (SNF) and radioactive waste. In the given geometry of the magnetic field, the plasma drift is associated with the deviation of ions from the axis of the system in the direction of the binormal to the magnetic field lines. In $[2,3]$, the mechanisms of purification of hydrogen plasma from impurities during drift in the magnetic field of a toroidal solenoid are considered. In particular, using the magnetic field of a toroidal solenoid, under experimental conditions [2], the possibility of cleaning a hydrogen plasma bunch from impurities located in the slow part of the bunch has been shown. In [4], the motion of a plasma in a toroidal plasma channel with a voltage applied to its wall is considered, and the features of the passage of high-energy and low-energy particles in it are investigated. In [5], in order to separate actinides and lanthanides, it is proposed to use an asymmetric magnetic trap to control the motion of heavy and light ions in a centrifugal magnetic mass filter. In [6], a conceptual design of the demonstrationimitation separator (DIS) for simulating SNF clean up from fission products in a plasma rotating in crossed electric and magnetic fields is presented. A nonradioactive mixture of oxides that imitate $\mathrm{SNF}$ is used as a working material. The main component is uranium238 dioxide. In this paper, we consider the configuration of the magnetic field of the DIS setup, which provides spatial separation of the actinide ions in a plasma from the ions of other type, collection of target ions $(\mathrm{M}=232 . .277)$ in a localized zone and a possible method of actinides removing from the separator into an external container.

\section{PARAMETERS OF THE DIS MAGNETIC SYSTEM}

The magnetic field of the DIS setup is developed using a combined system of windings: superconducting $-1,2$ and water-cooled $-3,4$ (Fig. 1). It is assumed that the working mixture of oxides simulating SNF enters the plasma source (PS) in the form of a micropowder.
Controlling the plasma flux under conditions of magnetization of heavy ions, in particular actinides, requires the creation of strong magnetic fields. For this purpose, it is proposed to use a magnetic system in the PS, which includes two superconducting solenoids with a constructive current density of $\sim 10^{4} \mathrm{~A} / \mathrm{cm}^{2}$. The geometry of the magnetic field in the PS affects the process of plasma formation and ensures its injection into the vacuum chamber of the plasma mass filter. In our case, a mirror-type magnetic system is created in the PS, formed by windings 1 and 2, with the maxima $\mathrm{B}(\mathrm{z}) \sim 3.2 \mathrm{~T}$ and $\mathrm{B}(\mathrm{z}) \sim 2.5 \mathrm{~T}$, respectively (Fig. 2). Creating a minimum magnetic field is provided by the selection of the current values of solenoids 1 and 2 and their location. A high degree of plasma ionization is achieved due to oscillations of electrons trapped in magnetic field and increasing the number of particles collisions in the plasma $\left(\mathrm{n}_{\mathrm{e}} \sim 10^{14} \mathrm{~cm}^{-3}, \mathrm{~T}_{\mathrm{e}} \sim 5 \mathrm{eV}\right)$. Earlier [7], the influence of the mirror ratio of the magnetic field on the parameters of the plasma formed in the uranium-lanthanum system was studied. In the magnetic system of the PS, the mirror ratio is 2.07 (see Fig. 2), which, according to [7], insignificantly affects the formation of plasma upon ionization of the working mixture containing $\sim 95 \%$ of actinide oxides by lowenergy electrons (up to $10 \mathrm{eV}$ ). An important role for trapping particles in the PS is played by the reflecting wall, where the outlet is located.

In the PS, the magnetized plasma components, moving along the force lines of an inhomogeneous axisymmetric magnetic field, are transported to the outlet $(\mathrm{r}=5 \mathrm{~cm})$. They include magnetized ions $(\mathrm{M}=232 \ldots 277)$, which are injected from the PS in the axial direction into the vacuum chamber of the separator.

In a zone between the coils 2 and 3 there is a strong decrease in the magnetic field, causing the appearance of the longitudinal component of the electric field $E_{z}$, the equipotentials of which are the magnetic field lines [4] and the motion of the plasma flux towards the coaxial electrodes, which create a radial electric field, $E_{r}$. As a result, the plasma drifts in a decreasing magnetic field at the transport of heavy ions to the separation area with a relatively weak magnetic field (see Fig. 2). 


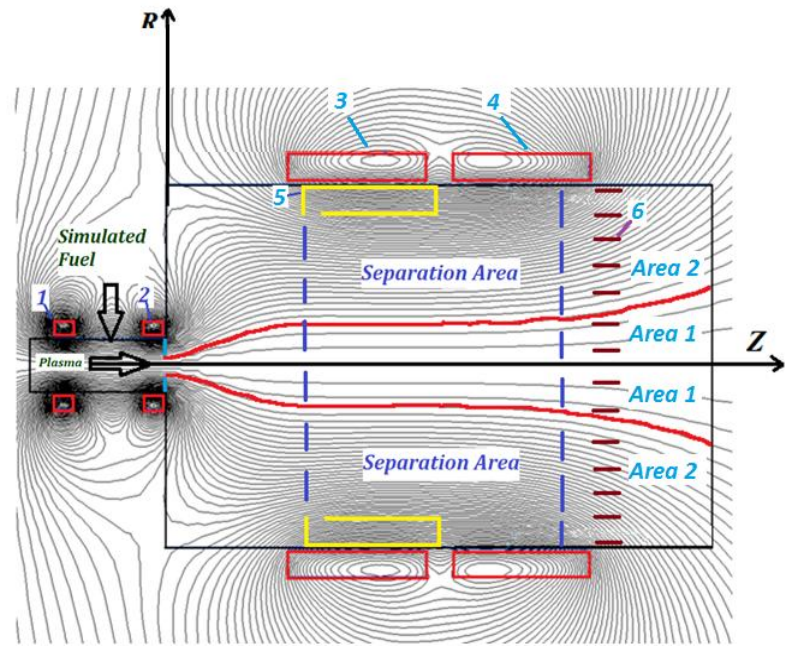

Fig. 1. The magnetic field lines created by the system of solenoids 1, 2, 3, 4 in the DIS setup; 5 -collector of actinides; 6 -coaxial electrodes for creating a radial electric field. The dotted lines are the boundaries of the separation area

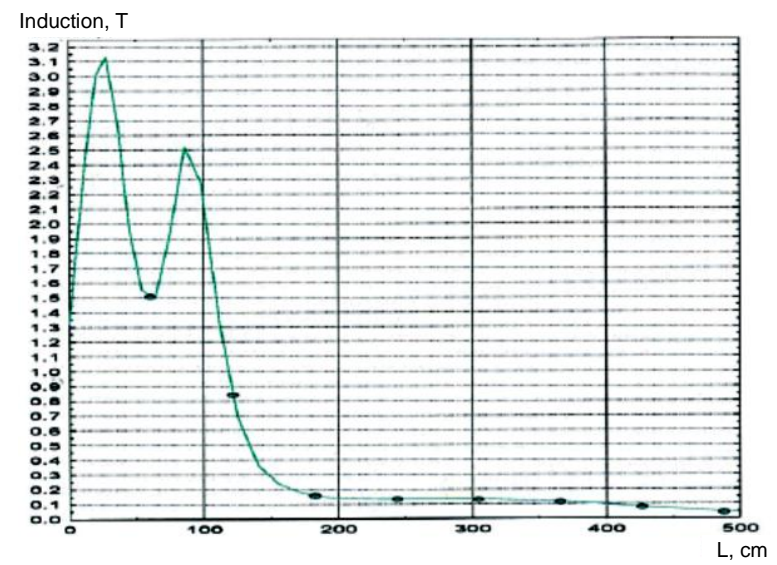

Fig. 2. Axial magnetic field distribution in the DIS setup

The induction (B) of magnetic field in the separator is determined by the axial and radial projections $B_{r}=\mathrm{B}(\mathrm{r})$ and $B_{z}=\mathrm{B}(\mathrm{z})$ in the plane $(\mathrm{r} \times \mathrm{z})$. The $B_{z}$ value is one of the parameters that affects the mass separation of ions in a plasma mass filter. In the separation area, where $\mathrm{Bz}$ is constant and the plasma is collisionless, spatial separation of ions of various types occurs (in our case, $B_{z}=0.1 \mathrm{~T}$ on the $\mathrm{z}$ axis at a plasma density of $\mathrm{n}_{\mathrm{e}} \sim 10^{11} \mathrm{~cm}^{-3}$ in the separation area). The components of $B_{r}$ and $B_{z}$ determine the specific features of the plasma drift in the cylindrical chamber of the separator. Based on the distribution of the magnetic field lines, in the separation area two areas can be conditionally distinguished (see Fig. 1). In the area 1 magnetized ions and electrons, which are injected from the PS, are transported along the magnetic field lines in the vacuum chamber of the separator. Note that in the area $1 B_{r}$ and $B_{\mathrm{z}}$ vary slightly (see the values of $B_{r}$ in the interval $0 \leq \mathrm{r} \leq 25 \mathrm{~cm}$ in Fig. $3, \mathrm{a}$ and $B_{z}$ in the interval $125 \leq \mathrm{z} \leq 250 \mathrm{~cm}$ in Fig. 3,b). The gradient and polarization drift of plasma is absent or not significant. In the area 2 the gradient $\nabla \mathrm{B} \neq 0$ and it depends on the magnetic field geometry (see the values of $B_{r}$ in the interval $25 \leq \mathrm{r} \leq 130 \mathrm{~cm}$ in Fig. 3 ,a and $B_{\mathrm{z}}$ in the interval $125 \leq \mathrm{z} \leq 250 \mathrm{~cm}$ in Fig. 3,b). At such conditions charged plasma particles change velocity, and a local charge in the plasma can occur, resulting in the appearance of electric polarization fields that affect the plasma drift.
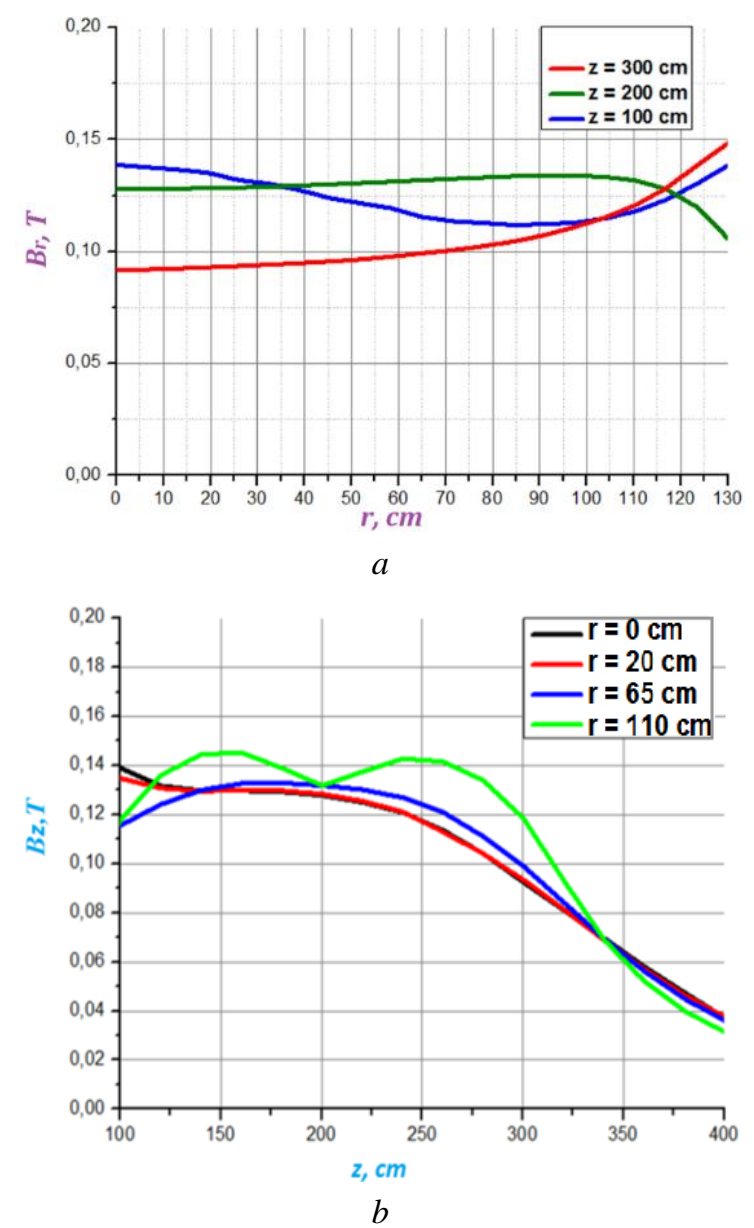

Fig. 3. Distribution of $B_{r}$ and $B_{z}$, respectively, along the radius $(a)$ and length $(b)$ in the DIS setup

In our case, the target ions $(M=232 \ldots 277)$ under the action of the electric field $E_{r}$ [7] are transported in the radial direction to the collector in the area 2 (see Fig. 1). The structure of the electric field in this area will affect the dynamics of the plasma, and the ion trajectories will deviate from the calculated ones in the one-particle approximation [7]. To remove the polarization fields in the separation area, it is necessary to compensate the space charge of the ions by electrons. To solve this problem, it is possible to use electron emitters, located in the area 2 , taking into account the equipotentials $E_{z}$, which are determined by the superposition of the magnetic fields of the separator coils. In addition, the electrons from the emitter will ionize the residual gases, forming a plasma with a density of $\sim 10^{11} \mathrm{~cm}^{-3}$ in the separator chamber. The parameters of the solenoids from the magnetic system of the plasma separator are presented in the Table. For cooling the superconducting windings in cryostats with liquid helium, it is possible to use, for example, industrial versions of a helium liquefaction plant with a capacity of $40 \ldots 50 \mathrm{~kW}$ [8]. Thus, the energy consumption for creating the magnetic field of the DIS setup by use of solenoids $1-4$ is at the level of $\sim 250 \mathrm{~kW}$. 
Parameters of the DIS solenoids

\begin{tabular}{|c|c|c|c|c|c|c|}
\hline Solenoid & $\begin{array}{c}\text { Current } \\
\text { density, } \\
\mathrm{A} / \mathrm{m}^{2}\end{array}$ & $\begin{array}{c}\text { Conductor } \\
\text { current, } \\
\mathrm{A}\end{array}$ & $\begin{array}{c}\text { Number } \\
\text { of turns }\end{array}$ & $\begin{array}{c}\text { Resistance, } \\
\Omega\end{array}$ & $\begin{array}{c}\text { Winding } \\
\text { length, } \\
\mathrm{m}\end{array}$ & $\begin{array}{c}\text { Power } \\
\text { consumption, } \\
\mathrm{kW}\end{array}$ \\
\hline 1 & $9 \cdot 10^{7}$ & 1350 & 995 & $\begin{array}{c}0 \text { (super- } \\
\text { conducting } \\
\text { mode) }\end{array}$ & 1124 & \multirow{2}{*}{$\begin{array}{c}\text { c } 50 \text { (general } \\
\text { cryosystem) }\end{array}$} \\
\hline 2 & $7 \cdot 10^{7}$ & 1050 & 995 & $\begin{array}{c}\text { 0 (super- } \\
\text { conducting } \\
\text { mode) }\end{array}$ & 1124 & \\
\hline 3 & $10^{6}$ & 600 & 600 & 0.27 & 5049 & 97.2 \\
\hline 4 & $10^{6}$ & 600 & 600 & 0.27 & 5049 & 97.2 \\
\hline
\end{tabular}

\section{ACTINIDES REMOVAL FROM PLASMA SEPARATOR}

To select a given mass range $(\mathrm{M}=232 \ldots 277)$ of ions (Fig. 4,a), a variable component of the electric field, $E_{r}$ with a frequency equal to half the cyclotron frequency of ions $(\mathrm{M}=238)$ is used, which ensures their separation from the ions of another varieties that are deposited on the end collector [9]. The collection of the target ions can be realized in a localized area of the cylindrical vacuum chamber of the separator, the socalled "pocket"-collector (see Fig. 4,b), wherein apart from $\mathrm{UO}_{2}{ }^{+}$, the ions of other actinides and their oxides can be collected. Ions deposition area is $\sim 15 \mathrm{~m}^{2}$. Inside there are grids with a high transparency coefficient to obtain a uniform distribution of deposited layer onto the collector surface [6].

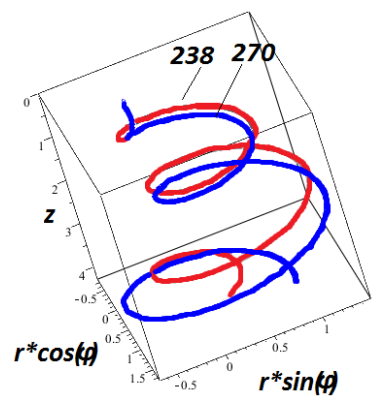

$a$

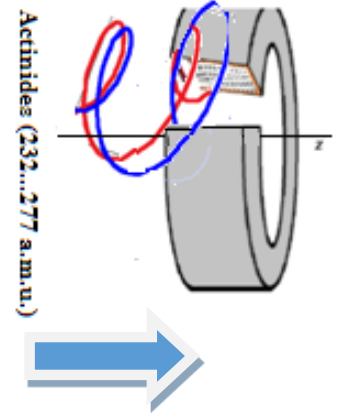

$b$

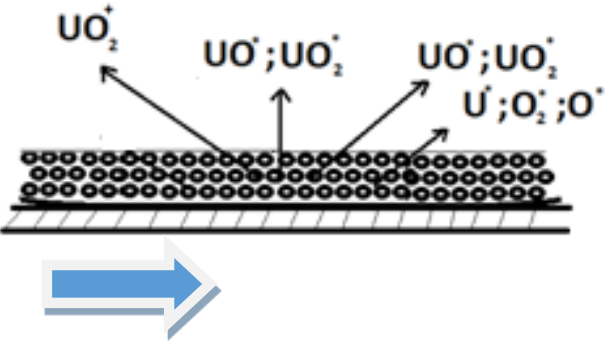

$c$

Fig. 4. The sequential process of separation and collection of actinides in the DIS setup: a-3D trajectories of uranium ions $(M=238)$ and uranium dioxide ions $(M=270)$ in the separator volume; $b-$ motion of ions of a given mass range $(M=232 . .277)$ into the "pocket"-collector; $c$-deposition of target ions onto the collector

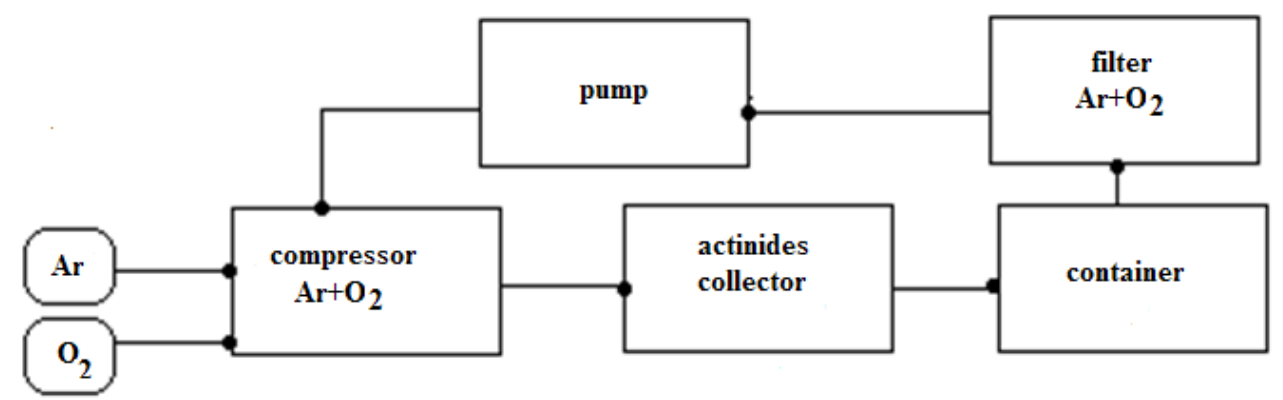

Fig. 5. Procedure of removing actinides from plasma separator to the container

It is expected that the deposition of target ions with an energy of $300 \ldots 500 \mathrm{eV}$ will be accompanied by sputtering of the deposit layer, formation of a multicomponent plasma and the presence of various plasma-chemical reactions in the "pocket"-collector (see Fig. 4,c).

After deposition of the ions onto the collectors, the plasma separation process ends. Then, a mixture of argon and oxygen is injected in the isolated zone of actinides collection. The converting of the main component $\mathrm{UO}_{2}$ into $\mathrm{U}_{3} \mathrm{O}_{8}$ occurs as a result of chemical reaction

$$
3 \mathrm{UO}_{2}+\mathrm{O}_{2} \rightarrow \mathrm{U}_{3} \mathrm{O}_{8}\left(\sim 700^{\circ} \mathrm{C}\right) .
$$

To remove the deposited layer of actinides from the "pocket"-collector, a purge system can be used, which consists of: a subsystem for injecting a mixture of gases of a given type at a temperature of $500 \ldots 700{ }^{\circ} \mathrm{C}$, a container for accumulating actinide oxides, evacuated pipes, a vacuum pump, vacuum valves, a compressor 
and a filter. In the cylindrical vacuum chamber, an opening with a fast-acting vacuum valve is provided for injecting a gas mixture under pressure into the area of the "pocket"-collector. A hole is provided on the inner surface of the "pocket" for removing actinide oxides under the influence of a pressure difference created by a vacuum pump, with the possibility of closing it with a fast-acting vacuum valve. The vacuum valve system ensures the tightness of the system and prevents the penetration of actinides from the "pocket" area.

An inlet of inert carrier gases, for example, argon, in a mixture with oxygen into the "pocket"-collector area, leads to a significant change in the forces that act in the condensed layer, to its cracking, a change in the parameters of the crystal lattice of $\mathrm{UO}_{2}$ and the converting of $\mathrm{UO}_{2}$ into $\mathrm{U}_{3} \mathrm{O}_{8}[10]$, after which the $\mathrm{U}_{3} \mathrm{O}_{8}$ powder together with other actinide oxides is blown out by the flow of a circulating gas mixture from the collector area into the container. Similarly, together with uranium, other actinides are converted into oxides. This technique could be a useful model for the production of MOX fuel for power reactors.

\section{CONCLUSIONS}

The parameters of the magnetic system of the demoimitation separator, which consists of a combination of superconducting and water-cooled windings, are presented. The features of plasma drift in a magnetic field of a given geometry are pointed. Two areas are conditionally identified inside the separation area, one of which is associated with the gradient and polarization drift. To compensate the space charge of the ions $(\mathrm{M}=232 \ldots 277)$ flux in this area, it is proposed to use electron emitters, located taking into account the equipotentials of $E_{z}$, the distribution of which is determined by the geometry of the magnetic field of the separator.

The estimation of the energy consumption for the creation of the magnetic field of the DIS, which is $250 \mathrm{~kW}$, has been carried out.

A method is proposed for actinides removing from the system using gas technologies, where a mixture of oxygen and argon is injected into the actinide collection area with further removal of the powder mixture of actinide oxides from the plasma separator into an external container.

\section{REFERENCES}

1. В.А. Жильцов, В.М. Кулыгин, Н.Н. Семашко и др. Применение методов плазменной сепарации элементов к обращению с ядерными материалами // Атомная энергия. 2006, т. 101, №4, с. 302-306.

2. В.С. Войценя, А.Г. Горбанюк, И.Н. Онищенко, Б.Г. Сафронов. Движение плотных плазменных сгустков в магнитном поле тороидального соленоида // ЖТФ. 1964, т. 34, в. 2, c. 281-287.

3. Н.С. Хижняк. Движение плазменного сгустка в магнитном поле тороидального соленоида // ЖТФ. 1965 , т. 35 , в. 5 , с. $847-855$.

4. В.А. Белоус, В.М. Хороших. Динамика плазмы вакуумной дуги в магнитном поле и системы формирования плазменных потоков // ФІП ФИП РSE, 2005, т. 3, № 1-2, c. 108-126.

5. A.J. Fetterman, N.J. Fisch. The magnetic centrifugal mass filter // Phys. Plasmas. 2011, v. 18, N 9, p. 09450392011; http//doi.org: 10/1063/1/3631793.

6. V.B. Yuferov, V.O. Ilichova, V.V. Katrechko, S.V. Shariy, A.S. Svichkar, M.O. Shvets, V.I. Tkachov, D.V. Vinnikov, A.N. Ozerov. The conceptual design of a demo-imitation separator - the model of a plasma mass filter for irradiated oxide uranium fuel // Problems of Atomic Science and Technology. Series "Plasma Physics". 2018, N 6(118), p. 289-292.

7. V.V. Katrechko, V.B. Yuferov, A.S. Svichkar, T.I. Tkachova, S.V. Shariy, V.O. Ilichova. Features of plasma formation for SNF magnetoplasma reprocessing at ionization stage // Problems of Atomic Science and Technology. Series "Plasma Physics". 2016, N 6(106), p. 238-240.

8. Каталог криогенной техники ГК «Криосистемы»»; https://www.cryosystems.ru.

9. V.V. Katrechko, V.B. Yuferov, V.O. Ilichova, S.N. Khizhnyak. Spatial separation of the ions of a given mass range in the demo-imitation separator at the first turn of ionic trajectory/l Problems of Atomic Science and Technology. Series "Plasma Electronics and New Methods of Acceleration”. 2021, N 4(134), p. 118-121; https://doi.org:10.46813/2021-134-118.

10. J. Svedkauskaite-Le Gore, N. Kivel, J.J. Gunter-Leopold. Real time measurement of fission products released from spent fuel by thermal treatment // $J$. Radioanal Nucl. Chem.;

DOI 10.1007|s10967-012-2046-X.

Article received 09.12.2021

\section{ВЫДЕЛЕНИЕ АКТИНОИДОВ В ДЕМОНСТРАЦИОННО-ИМИТАЦИОННОМ СЕПАРАТОРЕ С МАГНИТНЫМ ПОЛЕМ ЗАДАННОЙ КОНФИГУРАЦИИ}

\section{В.Б. Юферов, В.В. Катречко, В.О. Ильичева, С.Н. Хижняк}

Для моделирования очистки ОЯТ от продуктов деления отрабатывается концепция демонстрационноимитационного сепаратора с плазмой, вращающейся в скрещенных электрическом и магнитном полях. Представлены параметры магнитной системы, состоящей из комбинации сверхпроводящих и водоохлаждаемых обмоток. Отмечены особенности дрейфа плазмы в магнитном поле заданной геометрии. Проведена оценка энергозатрат на создание магнитного поля сепаратора, которая составляет 250 кВт. Предложен способ выведения актиноидов из плазменного сепаратора во внешний контейнер. 


\section{ВИДІЛЕННЯ АКТИНОЇДІВ У ДЕМОНСТРАЦІЙНО-ІМІТАЦІЙНОМУ СЕПАРАТОРІ З МАГНІТНИМ ПОЛЕМ ЗАДАНОЇ КОНФІГУРАЦЇ̈}

\section{В.Б. Юферов, В.В. Катречко, В.О. Ільічова, С.М. Хіжняк}

Для моделювання очищення ВяП від продуктів поділу відпрацьовується концепція демонстраційноімітаційного сепаратора 3 плазмою, що обертається в схрещених електричному та магнітному полях. Представлені параметри магнітної системи, яка складається з комбінації надпровідних обмоток й обмоток, що охолоджуються водою. Відзначено особливості дрейфу плазми в магнітному полі заданої геометрії. Проведена оцінка енергозатрат на створення магнітного поля сепаратора, яка складає 250 кВт. Запропоновано спосіб виведення актиноїдів з плазмового сепаратора в зовнішній контейнер. 